\title{
Building institutional capacity for industrial symbiosis \\ development: A case study of an industrial symbiosis coordination network in China
}

\author{
Qiaozhi Wang ${ }^{1}$, Pauline Deutz ${ }^{2}$, Yong Chen ${ }^{1, *}$ \\ 1 School of Resource and Environmental Engineering at Wuhan University of Science \\ and Technology, China \\ 2 Geography, School of Environmental Sciences at University of Hull, UK
}

This is the final manuscript of a paper published in the Journal of Cleaner Production.

Please site as follows:

Wang, W. Deutz, P. and Chen, Y. (2017) Building institutional capacity for industrial symbiosis development: A case study of an industrial symbiosis coordination network in China. Journal of Cleaner Production v. 142 1571-1582 doi.org/10.1016/j.jclepro.2016.11.146

Accepted for publication Accepted 23 November 2016

Published online December 182016

\footnotetext{
${ }^{*}$ Corresponding author

E-mail Address: wangqiaozhi@wust.edu.cn (Q. Wang), p.deutz@hull.ac.uk (P. Deutz), yongchen1968@163.com (Y. Chen)
} 


\begin{abstract}
Recent research has examined how the concept of institutional capacity relates to the ability of organisations to deliver industrial symbiosis, and in particular how that ability itself can develop over time. One approach to developing industrial symbiosis has been to build a network of local bodies to work together to this end. Terming such a body an industrial symbiosis coordination network, this study innovatively applies institutional capacity building theory in the context of a Chinese eco-industrial park. It examines how the coordination network developed the expertise to encourage local companies to engage in industrial symbiosis. This research consisted of a qualitative study, including participant observation, semi-structured interviews and document analysis to analyse the development of an industrial symbiosis coordination network in Tianjin Binhai New Area. It is found that the network increased institutional capacity for local IS development by promoting relational links across organisational divisions and governance levels, and by increasing various types of knowledge for coordinating IS. The concept of institutional capacity building is shown to have cross-cultural applicability. Reflections on this study indicate that local government can play a vital role in building and maintaining an IS coordination network in the Chinese context, but that other bodies are also needed to mobilise institutional capacity for IS development.
\end{abstract}

Key Words:

Industrial Symbiosis, Coordination Network, Institutional Capacity, China, Circular Economy, Eco-industrial Park, Resource Efficiency 


\section{Introduction}

Industrial Symbiosis (IS) refers to one entity's under-utilised resource, including byproducts, waste and energy streams becoming an input for another entity (Chertow, 2000; Deutz, 2014). The IS literature has identified certain canonical cases of IS in United States, Finland, Sweden, Denmark, Australia, South Korea, United Kingdom (Chertow, 2000; Mirata and Emtairah, 2005; Jacobsen, 2006; Park et al., 2008; Van Beers et al., 2008; Sokka et al., 2011; Rehn, 2013), and increasingly cases from China (Mathews and Tan, 2011; Yu et al., 2014a). Different approaches have been used to incentivise, encourage or facilitate the forming of IS relationships between companies on a local to national scale. For example, the eco-industrial park (EIP) development approach stresses green building design, integrated waste treatment facilities, or targeted tenant recruiting policies, to reduce waste emission within a park-level area (Deutz and Gibbs, 2008; Park et al., 2008; Shi et al., 2010). This method promotes IS through policies and planning to develop the supporting 'hardware' (e.g. infrastructure) of an EIP. However, whilst this hardware might provide the context for inter-firm relationships, in practice development of IS can be limited by contextual constraints beyond the EIP developers' control. In the US context, for example, locational factors contributed to challenges in recruiting complementary companies (e.g., Deutz and Gibbs, 2008). There are thus contextual constraints on what an IS project can achieve which are beyond its control.

Recent research has begun to consider how projects to promote IS and related cleaner production processes might learn from the processes they undertake and be able to improve their performance within those constraints (Boons and Spekkink, 2012; Spekkink, 2013; Van Hoof, 2015). This has been done through the lens of the concept of institutional capacity building. Healey et al (2003) used the term of institutional capacity (characterised by knowledge resources, relational resources and mobilisation capacity) to describe the ability of administrative and government organisations and agencies to respond to and resolve collective problems. These features are dynamic properties that can evolve over time as the policy process unfolds in its social, cultural and economic context. IS can be seen as such a process, likewise embedded in its context. Institutional capacity building has been applied to resource efficiencies (see 
below) in the context of IS generation in the Netherlands (Boons and Spekkink, 2012; Spekkink, 2013) and co-operation for cleaner production in Colombia (Van Hoof and Thiell, 2015). It has not, however, been previously applied to IS in China.

In China, EIPs have been a major national policy tool to promote resource efficiency in the context of the Circular Economy ( $\left.\mathrm{CE}^{1}\right)$ policy (Geng and Zhao, 2009). There has been widespread interest amongst park management in promoting resource efficiency and other environmental activities in response to targets imposed upon them (Chertow and Ehrenfeld, 2012; Yu et al., 2014c). IS has been seen as a method by which to achieve the required resources efficiencies, and has been promoted in part through drawing upon experiences of other regions or countries (Geng and Zhao, 2009; Zhang et al., 2010; Shi et al., 2012).

One such pilot EIP is Tianjin Economic-Technological Development Area (TEDA), which collaborated with a UK environmental services company (International Synergies Limited, ISL) to implement a four-year funded IS project ${ }^{2}$ in Tianjin Binhai New Area (TBNA, a broader area of TEDA) (Wang et al., 2012; Wang, 2013). The main purpose of the TBNA IS project was to encourage local companies to engage in the exchange of residues, and pinpoint future waste policy supporting sustainable industrial development (TEDA AC, 2009). However, ISL was only one component of several organisations assembled by TEDA administrative committee (AC), the local government, to provide collectively the information, knowledge, expertise and skills required to aid in IS development. We term this group of organisations and individuals an IS coordination network.

In this research, the forming and operating of an IS coordination network to implement the TBNA IS project is viewed as an institutional capacity building process for resolving economic, technological and policy problems regarding implementing IS activities in a Chinese industrial area. Here the institutional capacity building theory is

\footnotetext{
${ }^{1}$ Circular economy development refers to the promotion of resource conservation, cleaner production, re-utilisation, and environmental protection industries (State Council, 2005).

${ }^{2}$ Full name of the project is called Implementing Industrial Symbiosis and Environmental Management Systems in Tianjin Binhai New Area (Abbreviation: TBNA IS project).
} 
drawn upon to analyse the level of knowledge and relational resources and mobilisation capacity developed by the TEDA IS network through examining the research question: How has the IS coordination network formed in TEDA contributed to the development of institutional capacity for IS facilitation?

The structure of this article is as follows: section 2 describes the theory of institutional capacity building and clarifies the concept of IS coordination network introduced in this research; section 3 illustrates research methods and geographical background of the case study; section 4 presents results for the research question based on the case study; conclusions and proposals for further work are provided in section 5.

\section{Literature Review}

\subsection{Institutional Capacity building}

\subsubsection{Source of the Theory}

The concept of institutional capacity comes from the deliberative planning literature, referring to the ability of administrative organisations and agencies to respond to and resolve collective problems (Healey, 1998). According to Healey et al (2003), urban governance initiatives can be supported by a reservoir of capacities built from knowledge and relational resources which need to be deliberately activated to release their potential. Therefore, the authors stressed the significance of networks or arenas where mobilisation takes place and the role of key actors in initiating and managing governance innovations. The term 'institutional capacity building' was thus proposed to examine the processes of developing ability amongst and between governance actors in a locality to shape pilot and innovatory initiatives, and the potential for such initiatives to shift past practices (Healey, 1998; Healey et al., 2003).

Generally, the concept of institutional capacity building in an urban planning network has been analysed in terms of knowledge resources, relational resources and mobilisation capacities that they draw upon and develop (Healey et al., 2003; Polk, 2011). Relevant definitions for institutional capacity building and the approaches that have been employed to study them are presented in Table 1. Most significant of these is the mobilisation capacity, i.e., the ability to draw upon the available resources to achieve a goal. 
Table 1. Existing Definitions and Approaches to Understanding Features of

Institutional Capacity Building

\begin{tabular}{lll}
\hline $\begin{array}{c}\text { Component of } \\
\text { Institutional } \\
\text { Capacity }\end{array}$ & \multicolumn{1}{c}{ Definition } & \multicolumn{1}{c}{ Study Approach in the Literature } \\
\hline $\begin{array}{l}\text { Knowledge } \\
\text { resources }\end{array}$ & $\begin{array}{l}\text { Formal or tacit knowledge } \\
\text { operating at multiple levels } \\
\text { and developed by governance } \\
\text { actors to promote an issue } \\
\text { (e.g. urban regeneration }\end{array}$ & $\begin{array}{l}\text {-Exploring knowifered by network members } \\
\text { among network members }\end{array}$ \\
& project). & \\
\hline $\begin{array}{l}\text { Qualities of social relations } \\
\text { relational }\end{array}$ & $\begin{array}{l}\text {-Exploring whether the range of network } \\
\text { members sufficiently cover various sectors and }\end{array}$ \\
& $\begin{array}{l}\text { networks linking governance } \\
\text { actors together }\end{array}$ & $\begin{array}{l}\text { scales that are most relevant to the issue in an } \\
\text { area mirrors the quality of relational resources }\end{array}$ \\
\hline Mobilisation & $\begin{array}{l}\text { The capacity to activate } \\
\text { knowledge and relational }\end{array}$ & $\begin{array}{l}\text {-Exploring the concrete impact that the arena } \\
\text { of participants has had on a broader area }\end{array}$ \\
& $\begin{array}{l}\text { resources to meet network } \\
\text { goals, and to capture external }\end{array}$ & $\begin{array}{l}\text {-Seeking for evidence of new ways of working } \\
\text { in the local and regional policy making context } \\
\text { that can better promote network-level target. }\end{array}$ \\
\hline
\end{tabular}

Source: Author generated through drawing upon Healey (2003) and Polk (2011).

\subsubsection{Institutional Capacity Theory in the IS literature}

Boons et al (2011) introduced the concept of the institutional capacity building into the IS literature as successful cases of IS implementation resonate with scenarios from the planning literature. That is, IS development in a given locality reflects the ability of relevant organisations to collectively address the issue. That ability can be characterised as the extent to which they have built up the elements of institutional capacity. In IS terms, these elements are the availability and sharing of knowledge resources for conducting IS activities (e.g., information on available residues and potential local uses); relational resources (e.g., a level of trust built up between companies and other relevant actors to assist the reduction of transaction costs); and mobilisation capacity (actors' ability to activate relevant firms and other parties to develop symbiotic linkages). These ideas recognise the 'embeddedness' (Granovetter, 1985) of IS in the social, cultural and economic context within which it is progressing (Boons and Howard-Grenville, 2009).

Significantly, institutional capacity is dynamic rather than a static condition. The elements of institutional capacity and the relationships between them evolve over time (Boons et al., 2011; Van Hoof and Thiell, 2015). Companies already engaged in ISrelationships, for example, have been shown to have increased willingness to explore 
additional IS-related possibilities (Paquin and Howard-Grenville, 2012), which could be seen as an enriching of the local institutional capacity for IS through the experience of IS. Boons and Spekkink (2012) and Spekkink (2013) have attempted to directly investigate the relationship between institutional capacity building and the generation of IS-relationships. In a quantitative study of 233 projects aiming to develop EIPs in the Netherlands, Boons and Spekkink (2012) found that of the three elements of institutional capacity, only mobilisation capacity is a factor affecting participants' perceptions of feasible options for action (the 'opportunity set'). The result underscores the pre-eminence of mobilisation capacity as the critical element in institutional capacity building (Healey et al., 2003); knowledge and relational resources are necessary, but not sufficient to bring about IS (Boons and Spekkink, 2012).

By contrast, Spekkink (2013) carried out a detailed process analysis of development of IS in the Canal Zone in the Zeeland province on the Netherlands over a 10-year time period. Institutional capacity for IS took a step forward when a funded project began to work alongside the individual effort of companies. This development helped to form a shared vision incorporating IS. Although the opportunities for IS have been fairly few, the recognition of the common interest in IS enabled the seeking of additional expertise from beyond the locality (Spekkink, 2013). This is an example of a group consciously adjusting its membership to improve its institutional capacity, which supports the significance of mobilisation capacity.

Thus, Boons and his colleagues have introduced the perspectives of institutional capacity building theory as a means of studying the mechanism of generating regional IS (Boons et al., 2011; Boons and Spekkink, 2012; see Spekkink, 2013). However, they overlooked the different roles of two distinct networks relevant to local IS development 1) the network of facilitating actors (i.e., the IS coordination network) and 2) the network of firms engaged in IS. The two networks are interrelated but it is the latter actually implementing IS, whilst the former is contributing to a conducive and actively supportive policy context for IS (see figure 1). The recent IS literature more generally has paid close attention to the analysis of networks of companies engaging in IS (e.g. Schiller et al., 2014), but is relatively silent on the networks of organisations collectively involved in promoting it. 


\section{IS Coordination Network}

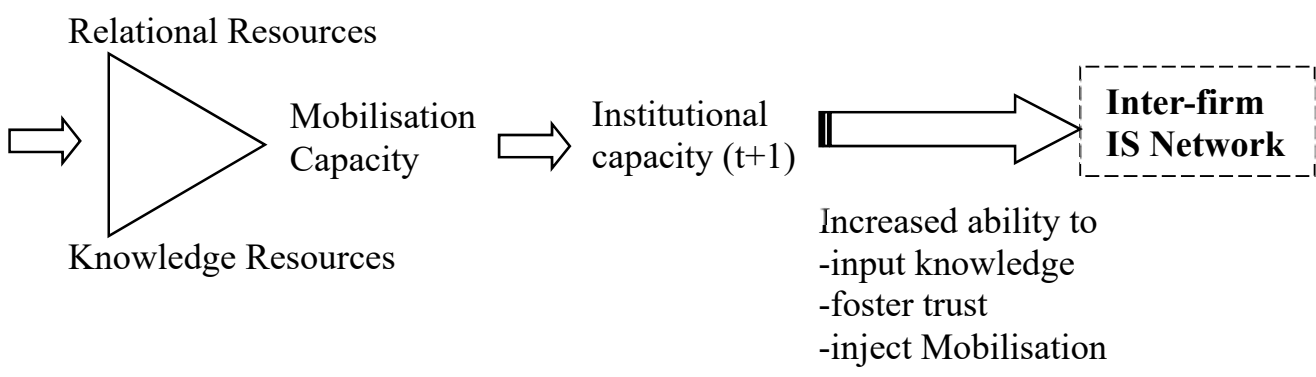

Figure 1. Relationship of the IS coordination network and inter-firm IS network Source: author generated, drawing on Healey (2003) and Boons and Spekkink(2012).

As illustrated in Figure 1, it is argued herein that the institutional capacity of the IS coordination network is increased with increased relational resources, knowledge resources and mobilisation capacity, and it will then lead to increased ability to input knowledge, foster trust and inject mobilisation into the local inter-firm IS network.

To date the application of institutional capacity to IS has been limited outside of a developed country, and largely European context. However, Van Hoof's (2015) study of a 10-year collaborative project to promote company environmental performance in Colombia indicates that institutional capacity building can be usefully applied in an emerging economy context, notwithstanding an often lower level of institutional capacity for environmental governance compared to the European setting where these ideas have emerged. The Chinese approach to EIPs has been characterised as driven by a national government initiative to set up a local organisational setting protective of environmental technology, including IS, as part of the drive to a CE (Shi and Yu, 2014). This is likewise a different institutional context to the regional process of building relationships for governance as considered by Healey et al. (2003) or the Dutch studies. The role of institutions in the development of Chinese IS has been studies by several authors (e.g. Shi et al., 2010; Wang et al., 2012, 2015, Yu et al., 2014c, 2015; Liu et al., 2015). Authors have analysed the institutional context, for example EIPs and the CE policy (e.g. Liu et al., 2015) and illustrated the cooperation of various government departments and organisations in promoting IS (e.g. Yu et al., 2015).The Chinese EIPs have therefore been involved in a process of relationship building as these new 
institutions sought to operate in their regional institutional setting (Shi and Yu, 2014; Yu et al., 2015). Here we examine how that processes of adjustment has influenced the building of institutional capacity for IS promotion.

\subsection{IS Coordination Network}

In the IS literature, the concepts of 'IS facilitation' and 'IS coordination' are both referred to as strategies for promoting IS, sometimes interchangeably (see Doménech and Davies, 2011; Mirata, 2004; Paquin and Howard-Grenville, 2012). However, the term 'IS facilitation' typically refers to having a third party organisation such as the national IS programme in the UK as a broker to deliberately encourage industry to implement IS synergies (i.e., an IS relationship between companies; e.g. Jensen et al., 2011). By contrast, 'IS coordination' tends to denote the involvement of multiple organisations and government agencies engaging in the IS facilitation process (e.g. Yu et al., 2014b).

In this research, coordination is defined according to the usage of the concept in the management literature, referring to patterns of action, formal or informal, that enhance information exchange and stimulate mutual understanding between coordinated entities (Dietrich, 2007). In addition, 'network' is understood as a structure involving multiple nodes, i.e. agencies and organisations with multiple linkages, working on crossboundary collaborative initiatives (McGuire and Agranoff, 2011). A network brings together the knowledge experience of the component organisations to attempt to align their actions with the network goals, leading to a more efficient use of resources and an increased capacity to deal with complex problems (Marques et al., 2011; Provan and Kenis, 2008).

Overall, an IS coordination network is considered herein to comprise organisations such as government departments, environmental services companies, academic institutions or persons that work together to promote inter-firm IS activities in a region. This differs previous research in which the coordinator is an individual (cf., IS champion, Hewes and Lyons, 2008), a government agency (cf., local environmental protection bureau, Shi et al., 2010), or an environmental services organisation (cf. UK national IS programme, Paquin and Howard-Grenville, 2012), or an industrial association (cf., Kwinana industrial council, Van Beers et al., 2008) that promotes or facilitates IS. In 
previous research, the impact of the coordinator is normally studied through exploring the growth of inter-firm synergies brought about by the coordinator; the role of coordinator is viewed to be crucial to the development of IS. However, the IS literature has not addressed how a network of coordinating bodies has played a role for IS development in terms of knowledge/relational resources and mobilisation capacity enhancement. This research therefore focuses on how different bodies involved have managed to combine the different types of capacity to achieve what they did. It therefore contributes to a better understanding of the significance of adopting an IS coordination network and could provide significant lessons to other industrial areas, especially Chinese, with the same goal of engaging waste management and the CE development.

To explore the research question on how the TEDA IS coordination network has contributed to the development of institutional capacity for IS facilitation, the several sub-questions are explored (as shown in Table 2).

Table 2. Sub-research questions for exploring the change of the institutional capacity with the formation TEDA IS coordination network

\begin{tabular}{|c|c|c|}
\hline Knowledge Resources & Relational Resources & Mobilisation Capacity \\
\hline $\begin{array}{l}\text { 1. Have knowledge } \\
\text { resources been increased } \\
\text { for promoting inter-firm } \\
\text { IS activities? }\end{array}$ & $\begin{array}{l}\text { 3. Have relational links across } \\
\text { organisational divisions and } \\
\text { governance levels increased for } \\
\text { coordinating IS? }\end{array}$ & $\begin{array}{l}\text { 5. Are there new ways of } \\
\text { working in the area for } \\
\text { coordinating IS that can better } \\
\text { promote IS development? }\end{array}$ \\
\hline $\begin{array}{l}\text { 2. How have the } \\
\text { knowledge resources } \\
\text { been increased? }\end{array}$ & $\begin{array}{l}\text { 4. Which approaches have been } \\
\text { adopted to enhance network } \\
\text { member's relations? }\end{array}$ & $\begin{array}{l}\text { 6. How have new ways of } \\
\text { coordinating IS been formed? }\end{array}$ \\
\hline
\end{tabular}

Source: author generated primarily drawing upon Polk (2011), and Healey et al (2003).

The six sub-research questions centre on key components of institutional capacity: knowledge resources, relational resources, and mobilisation capacity. Exploring these questions potentially identify features or indicators embodying each component.

\section{Research Methods and Geographical Background}

\subsection{Research Methods}

This research adopts a case study approach, as has been frequently used to understand 
a real-life phenomenon in-depth, and to study specific programmes, projects, and initiatives to document and analyse the implementation processes (Yin, 2008, 2012). Case study research covers the exploration of a contemporary phenomenon in one or more cases (e.g. an event, a process, or a particular place) within one or more bounded system(s) (e.g. context) through detailed and in-depth data collection (e.g. through observations, interviews and documents), and presents a case description and casebased themes (Baxter, 2010; Creswell, 2012).

Research was conducted in three phases: a preliminary desk analysis, on-site and follow-up activities. The desk analysis started with a literature review conducted by a keywords search (such as industrial symbiosis, network coordination, etc). Meanwhile, the background information of eco-industrial development in Tianjin EconomicTechnological Development Area (TEDA) was collected using website materials and secondary literature. The desk analysis aided in the formation of the boundaries of the case study, the identification of key stakeholders involved, and the methods of data collection and processing.

On-site activities were conducted between 2010 and 2012 during the first author's one month internship with the TEDA Eco-centre and 3 months with International Synergies Limited (ISL). TEDA Eco-centre was implementing an industrial symbiosis programme with the guidance of ISL during that time. After being informed of the first author's $\mathrm{PhD}$ research exploring the process mechanism of transferring a UK-based IS network coordination approach to China, the two organisations invited the author to collect data and do a short-term internship. The internship provided the researcher opportunities to do in-depth semi-structured interviews and observe the process of implementing the IS network coordination strategy in TEDA. Details of interviews exploring the research question of this study are presented in Table 3.

Table 3 Details of interviews

\begin{tabular}{l|l|l|l|l}
\hline $\begin{array}{l}\text { Interviewee } \\
\text { No. }\end{array}$ & Affiliation & $\begin{array}{l}\text { Interview } \\
\text { date }\end{array}$ & Interview type & Major Interview topics \\
\hline \multirow{2}{*}{ A } & ASL & Apr. 2010 & $\begin{array}{l}\text { semi- } \\
\text { structured }\end{array}$ & $\begin{array}{l}\text { The origination of the ISL-China } \\
\text { collaboration; the person's role } \\
\text { and experiences in the programme } \\
\text { and knowledge sharing process. }\end{array}$ \\
\cline { 3 - 5 } & Jan. 2016 & Email & Final report of TBNA IS project \\
\hline
\end{tabular}




\begin{tabular}{|c|c|c|c|c|}
\hline & & & & $\begin{array}{l}\text { and ISL's satisfaction to the } \\
\text { project }\end{array}$ \\
\hline B & $\begin{array}{l}\text { TEDA } \\
\text { eco-centre }\end{array}$ & Apr. 2010 & $\begin{array}{l}\text { semi- } \\
\text { structured }\end{array}$ & $\begin{array}{l}\text { The origination of the ISL-China } \\
\text { collaboration; the person's role } \\
\text { and experiences in the programme } \\
\text { and knowledge learning and } \\
\text { application process. }\end{array}$ \\
\hline $\mathrm{C}$ & $\begin{array}{l}\text { TEDA } \\
\text { Environmental } \\
\text { Protection } \\
\text { Bureau }\end{array}$ & Mar. 2010 & $\begin{array}{l}\text { semi- } \\
\text { structured }\end{array}$ & $\begin{array}{l}\text { The progress and problems of } \\
\text { running the TBNA IS network } \\
\text { programme at the early stage. }\end{array}$ \\
\hline D & ISL & Nov. 2010 & $\begin{array}{l}\text { semi- } \\
\text { structured }\end{array}$ & $\begin{array}{l}\text { The progress and problems of } \\
\text { running the TBNA IS network } \\
\text { programme. }\end{array}$ \\
\hline $\mathrm{E}$ & ISL & Jun. 2012 & $\begin{array}{l}\text { semi- } \\
\text { structured }\end{array}$ & $\begin{array}{l}\text { Progress of the TBNA IS Network } \\
\text { programme, the person's role and } \\
\text { experiences in the programme and } \\
\text { knowledge sharing process. }\end{array}$ \\
\hline $\mathrm{F}$ & $\begin{array}{l}\text { TEDA } \\
\text { centre }\end{array}$ & Jun. 2016 & $\begin{array}{l}\text { Email } \\
\text { Interview }\end{array}$ & $\begin{array}{l}\text { Recent IS coordination activities } \\
\text { in TEDA }\end{array}$ \\
\hline
\end{tabular}

Data collected through participant observation were recorded through meeting attendance notes and internship diaries based on the guidance of DeWalts (2011). Follow-up activities were conducted through email about participants' attitudes towards the TBNA IS project between 2014 and 2016.

In addition, a number of Tianjin municipal and park-level government officials in charge of regional or local economic, environmental and industrial development were communicated with when the researcher was accompanying them to visit UK businesses with synergies facilitated by ISL. The communications assisted the researcher's understanding of their interpretation of the IS concept and the manner of collaboration among different Chinese government departments for IS development in TEDA (see Wang, 2013).

During the interviews and participant observation process, the researcher contacted the participants in advance to get their permission to conduct the fieldwork. They were informed about the researcher's identify and research objectives. As promised, when their comments were cited in the dissertation, their names were withheld; interviewees are identified only by their position. All quotes used in the study are from formal interviews. Participation in workshops and other activities during the internship helped to increase the first author's understanding of the processes involved and their relevance to the context. However, reference is made only to the outcomes; no direct reference is 
made to specific information (such as individuals' responses) gained from that experience.

\subsection{Geographical Background of the Case Study}

Developed since 1984, TEDA is a $33 \mathrm{~km}^{2}$ industrial area located 45 kilometres east of Tianjin municipality and 130 kilometres southeast of China's capital city, Beijing. Figure 2 presents the geographical location of TEDA (TEDA Eco-centre, 2011).

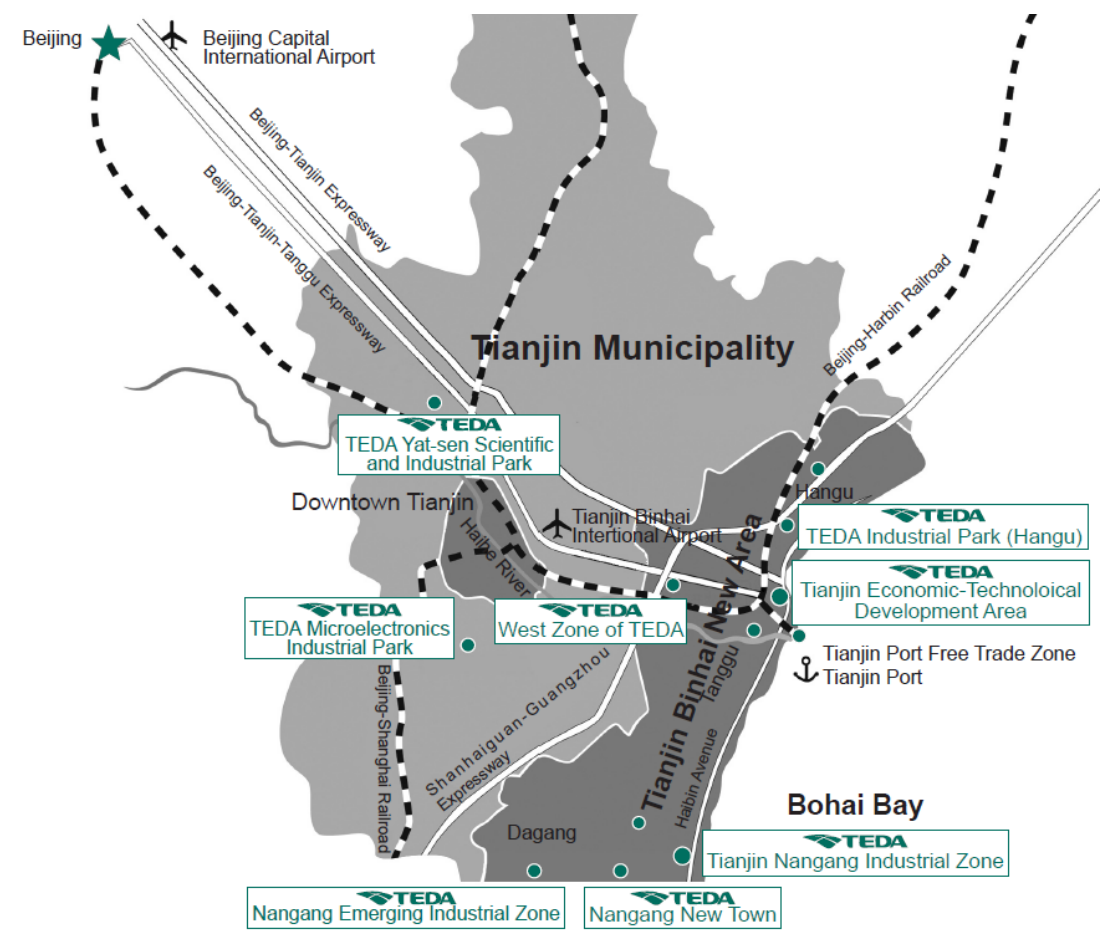

Figure 2. The Location of TEDA

Industries operating in the area currently include electronics and information, automotive and machinery, petroleum and chemicals, modern metallurgy, biotechnology and pharmaceuticals, new energy and materials, and food processing. Industries which are currently entering include aviation, finance, and services (TEDA, 2011a, 2011b).

TEDA has attempted to implement the EIP concept since 2001 and was selected as the 'Environmental Management Pilot Project for Chinese Industrial Parks' sponsored by the State Environmental Protection Administration (SEPA) and the United Nations Environment Programme (UNEP). It was in the first batch of National Pilot Circular Economic Park in 2005 by the SEPA and awarded the status of a "National 
Demonstrative EIP' in 2008 (TEDA, 2011a).

As illustrated by Shi et al (2010), before 2010, the park-level government (TEDA administrative Commission) and the local Environmental Protection Bureau (EPB) were promoting the policy context affecting firm waste management activities. The promotion approaches primarily included developing waste treatment facilities, and implementing new environmental programmes such as environmental impact assessment of new investment projects, environmental monitoring of existing key water and air pollution sources, pollution discharge levies, total pollutant emission control, and other initiatives. Although the aforementioned activities are not directly aiming at forming symbiotic links between firms, they helped to form awareness of environmental practices that can open the way for IS. TEDA EPB was involved directly in discovering inter-firm IS opportunities through implementing the EU-China Environmental Management Cooperation Programme $\left(\mathrm{EMCP}^{3}\right)$. Since 2010, TEDA Eco-centre, with the support of local and regional government departments (as shown in Figures 3 and 4), has been working on coordinating inter-firm IS and other lowcarbon activities. Launched in March 2010, TEDA Eco-centre was set up by TEDA Administrative Commission to integrate resources of different government departments to deliver TBNA IS programme (TEDA Eco-centre, 2011).

Previous research into IS development in TEDA has described primary stakeholders involved in promoting regional IS involving the park-level AC, the local EPB and other government departments and the newly founded eco-centre as well as the national policy context for IS implementation (Geng et al., 2007; Qi et al., 2009; Shi et al., 2010; Wang et al., 2012, 2015; Yu et al., 2014b). In this paper, the impact of the IS coordination network is explored from the perspective of institutional capacity building theory.

\footnotetext{
${ }^{3}$ EMCP promotes environmental governance development in China financed by the European Commission (EMCP, 2013).The programme delivery process covered exploring synergy opportunities based on the waste streams surveys and developing an on-line waste exchange system (TEDA, 2005). A number of prior synergies were identified by the EPB to provide funding support including condensate reuse and composting of traditional Chinese medicine residues(TEDA AC, 2006).
} 


\section{Case study}

\subsection{Motivation and composition of an IS Coordination network with Cross-sector Collaborations in TEDA}

The motivation driving the TEDA administrative committee (AC) to set up an IS coordination network was the ambition to be the leading EIP engaging IS activities in China and the awareness of the need of technology, expertise, funding support from other organisations and policy support from upper level of government. Summarised from TEDA AC's project proposal (TEDA AC, 2009), the needs and constraints for the local area to develop IS can be summarised as follows:

- There was no effective institution or information network for local industries to identify potential synergies for efficient resource management;

- Little expertise existed to support the implementation of synergy opportunities identified;

- There was a potential partner (ISL) with mature tools and systems of IS coordination which had been applied in the UK for more than five years.

Beginning in 2009, TEDA AC has developed an IS coordination network to support the delivery of the TBNA IS project and other projects promoting low carbon development (TEDA Eco-centre, 2011). This can be viewed as a process of building a facilitation capacity through accessing the collective knowledge resources of the members. The latter, however, were not only at facilitating IS, they were also inexperienced at working with each other. Forming the network, therefore, was only an initial step towards building the relational resources and developing a collective mobilisation capacity to bring about IS.

Formal foundation of the IS coordination network happened in March 2010 with the launch event of TEDA Eco-centre. As the eco-centre is a local government-owned nonprofit organisation providing environmental services to local industries and communities, the director was seconded from TEDA EPB. Another five people were recruited to work in the eco-centre at that time. Regarding the need to set up an ecocentre, the deputy director of the local government made the following comments to media: 'Sufficient information on low-carbon technology, expertise and experience are still not sufficient to enhance energy efficiency and protecting the environment in 
TEDA. That is where the centre can play a role. It is supposed to serve as a platform for information sharing and exchanging' (Wang, 2010).

The eco-centre therefore acted as a platform for collaborations among multiple levels of government departments and foreign organisations. At the first steering committee meeting, the role of the primary participants in the IS coordination network was clarified as shown in Figure 3:

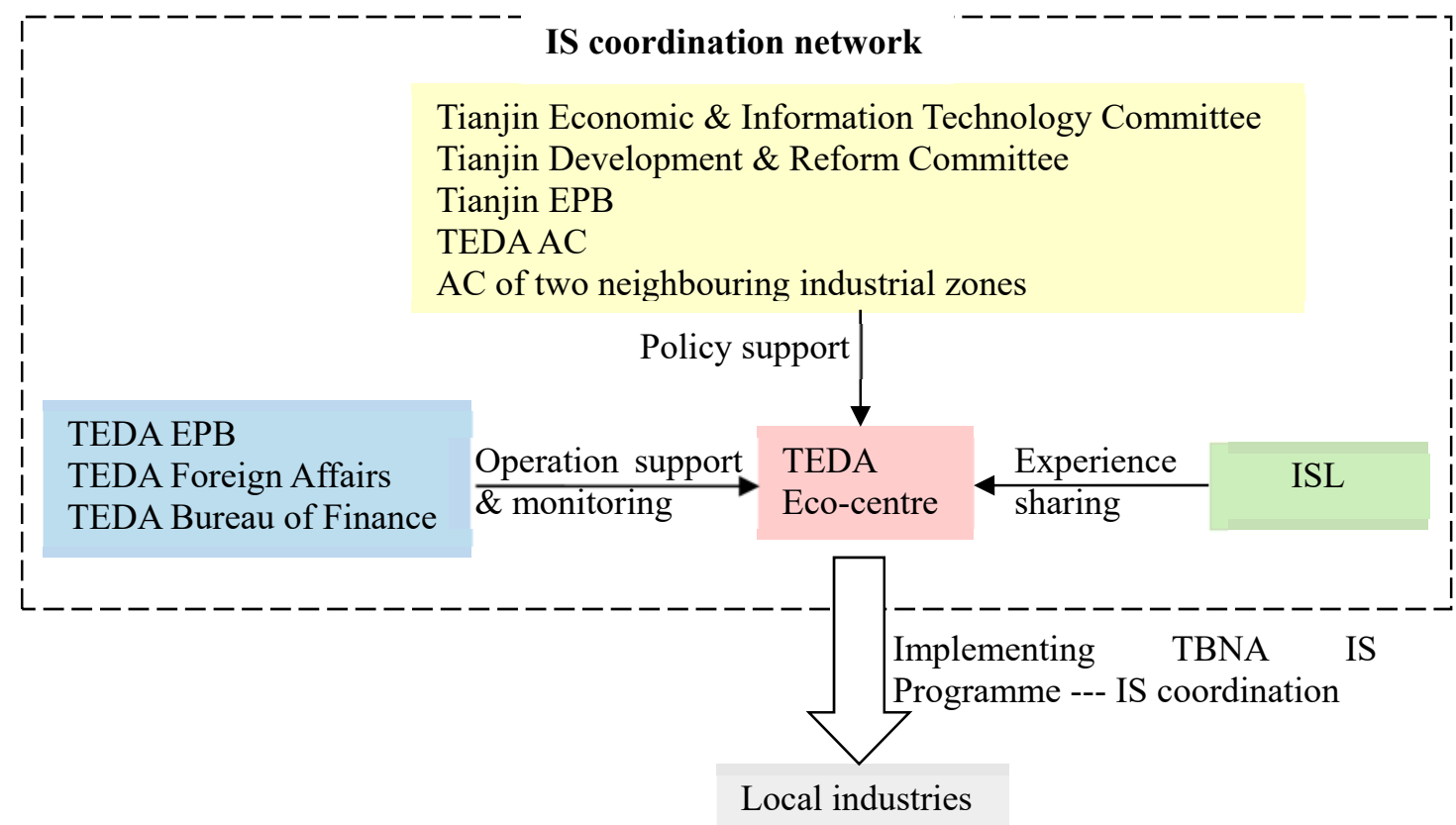

Figure 3. Primary participants in the IS coordination Network

Source: the first author generated through meeting notes taken on the first steering committee meeting hold on $26^{\text {th }}$ March 2010

The hub of the IS coordination network is TEDA Eco-centre (Figure 3). With the support of TEDAAC, the eco-centre was set up and has worked on integrating resources from a range of local and regional government departments to deliver the IS coordination function. Besides the involvement of multiple organisations in the IS coordination network, a number of individual participants (experts from academic institutions or consultancies) were invited by TEDA AC to support activities of the IS coordination network. 


\subsection{Institutional capacity for facilitating IS activities derived from the coordination network}

\subsubsection{Knowledge Resources Development}

Before the initiation of the IS coordination network, it was the local EPB that worked on encouraging the utilisation of waste residues to reduce industrial solid pollutants. IS coordination expertise was primarily in the field of environmental management approaches. There was a lack of expertise and manpower for coordinating IS, i.e., they had experience at advising companies individually on environmental management, but no experience at trying to forge links between companies. The problem was exposed in the local EPB's delivery of EU-China Environmental Management Cooperation Programme (EMCP) between 2003 and 2005.

"They [TEDA EPB staff] have profound experience working with local industries through delivering the EMCP project. They were quite busy and could only part-timely work for the project [...] It was environmental, a section of government. So, their knowledge of dealing with companies on a business footing was not that great..."

---by staff member A from ISL, semi-structured interview, 2010 April

"I think the main barrier is personnel. It was some EPB staff part-timely doing the IS project. That project [EMCP] needs more investment on manpower, time and material resources."

---by a former TEDA Eco-centre staff B, semi-structured interview, 2010 April

"This [TBNA IS Programme] is only a four year programme. As a government department, we can't easily recruit persons. Personnel recruitment in the government is conducted through the annual national civil servant exam ${ }^{4}$."

--- by staff C from TEDA EPB, semi-structured interview, 2010 March

The method adopted to overcome the lack of expertise and manpower for facilitating local IS was to develop an eco-centre supported by the local government to organise knowledge resources. Actors participating in the IS coordination network are top administrators and practitioners in government departments or organisations responsible to promote resource re-utilisation. The network therefore includes a range of knowledge that exists in government agencies and organisations listed in Table 4.

\footnotetext{
${ }^{4}$ As mentioned by Chan and $\mathrm{Li}$ (2007), jobs for civil servant are normally supposed to be permanent.
} 
Table 4. A classification of primary knowledge sources in the IS coordination network

\begin{tabular}{|c|c|c|c|}
\hline $\begin{array}{l}\text { Knowledge } \\
\text { Types }\end{array}$ & $\begin{array}{l}\text { Knowledge } \\
\text { sources }\end{array}$ & Details of the knowledge & $\begin{array}{l}\text { Impact of the knowledge } \\
\text { on IS coordination }\end{array}$ \\
\hline \multirow[t]{2}{*}{$\begin{array}{l}\text { Policy } \\
\text { knowledge }\end{array}$} & $\begin{array}{l}\text { Multiple } \\
\text { levels of } \\
\text { government } \\
\text { departments }\end{array}$ & $\begin{array}{l}\text { Expertise in local environmental, } \\
\text { economic and industrial } \\
\text { development policy development } \\
\text { and regulatory management }\end{array}$ & $\begin{array}{llr}\text { Providing policy } & \text { and } \\
\text { regulatory support } & \text { for } \\
\text { implementing IS } & \end{array}$ \\
\hline & ISL & Mastering UK waste policies & $\begin{array}{l}\text { Bringing in British } \\
\text { experiences }\end{array}$ \\
\hline \multirow[b]{2}{*}{$\begin{array}{l}\text { Technological } \\
\text { knowledge }\end{array}$} & $\begin{array}{l}\text { Academic } \\
\text { institutions }\end{array}$ & $\begin{array}{l}\text { Expertise in Chinese waste disposal } \\
\text { techniques and industrial } \\
\text { production process }\end{array}$ & $\begin{array}{l}\text { Identifying } \\
\text { technologically feasible } \\
\text { synergies for plants }\end{array}$ \\
\hline & ISL & $\begin{array}{l}\text { Information and Communications } \\
\text { Technology supported knowledge } \\
\text { in British waste disposal } \\
\text { techniques, industrial production } \\
\text { process and innovative IS solutions }\end{array}$ & $\begin{array}{l}\text { Assisting } \\
\text { identification } \\
\text { bringing in } \\
\text { experiences }\end{array}$ \\
\hline \multirow[t]{2}{*}{$\begin{array}{l}\text { Networking } \\
\text { facilitation } \\
\text { knowledge }\end{array}$} & ISL & $\begin{array}{l}\text { Skills of communicating with } \\
\text { industries in the UK, organising } \\
\text { inter-firm network events for } \\
\text { promoting IS, and recording } \\
\text { available and required resources } \\
\text { through using its proprietary and } \\
\text { project management software } \\
\text { (SYNERGie) }\end{array}$ & $\begin{array}{l}\text { Building trust among } \\
\text { industries in the UK, and } \\
\text { improving the efficiency } \\
\text { of data management }\end{array}$ \\
\hline & $\begin{array}{l}\text { TEDA Eco- } \\
\text { centre }\end{array}$ & $\begin{array}{l}\text { Skills of communicating with local } \\
\text { industries, local government } \\
\text { departments, and international } \\
\text { organisations to disseminate } \\
\text { sustainable industrial knowledge }\end{array}$ & $\begin{array}{l}\text { Promoting dialogue and } \\
\text { collaboration among } \\
\text { different organisations for } \\
\text { sustainable industrial } \\
\text { development }\end{array}$ \\
\hline
\end{tabular}

Source: Author generated through interviews and participant observation.

Compared to knowledge resources owned by the previous coordinator (TEDA EPB), knowledge resources in the IS coordination network covered expertise to coordinate business-networking to generate IS opportunities and resolve policy and technological problems occurring in implementing IS.

The exchange of the different knowledge sources between the members of the coordination network occurred in various platforms, including primarily training courses, on-site guidance, policy tour and periodical meetings.

- Training courses: Staff in TEDA Eco-centre accepted a-week training courses from ISL. The courses have covered operating the software (SYNERGie) to record available and required resources from industries and identifying potential synergy opportunities, 
coordinating TBNA IS projects through organising inter-firm networking events, communicating with industries, conducting site visits to industries to collect detailed data, and tracking and reporting the progress of coordinated synergy projects.

- On-site guidance: ISL dispatched staff to guide inter-firm networking and site visits events conducted by the eco-centre four times per year. Also, experts from academic institutions were invited to assist site visits to local industries to diagnose synergy opportunities.

- Policy tour: With the guidance of ISL, TEDA Eco-centre and involved government departments dispatched two groups of staff per year to visit UK to build a deep understanding of the UK waste policy context. Generally two types of events were arranged for policy tours: firstly, visiting a number of businesses such as electronic manufacturers, anaerobic digestion plants and waste recycling centres to observe successful IS practices; secondly, communicating policy makers government departments such as Birmingham city council and Department for Environment, Food and Rural Affairs (DEFRA) to understand regional and national level policy practices to promote landfill diversion.

- Periodic meetings: Internal meetings were held periodically to track the progress of the project and event planning. Weekly technical telephone conferences were held between TEDA Eco-centre and ISL to discuss specific technical issues; management telephone conferences were held on a regular basis between TEDA AC, ISL and UNIDO, to ensure management focus on the key strategic issues at hand.

\subsubsection{Relational Resources}

As discussed in section 2.1.1, the quality of relational resources of the IS coordination network can be determined through exploring whether the range of network members increasingly covers various sectors that are most relevant to IS promotion (see Healey et al., 2003; Polk, 2011). 


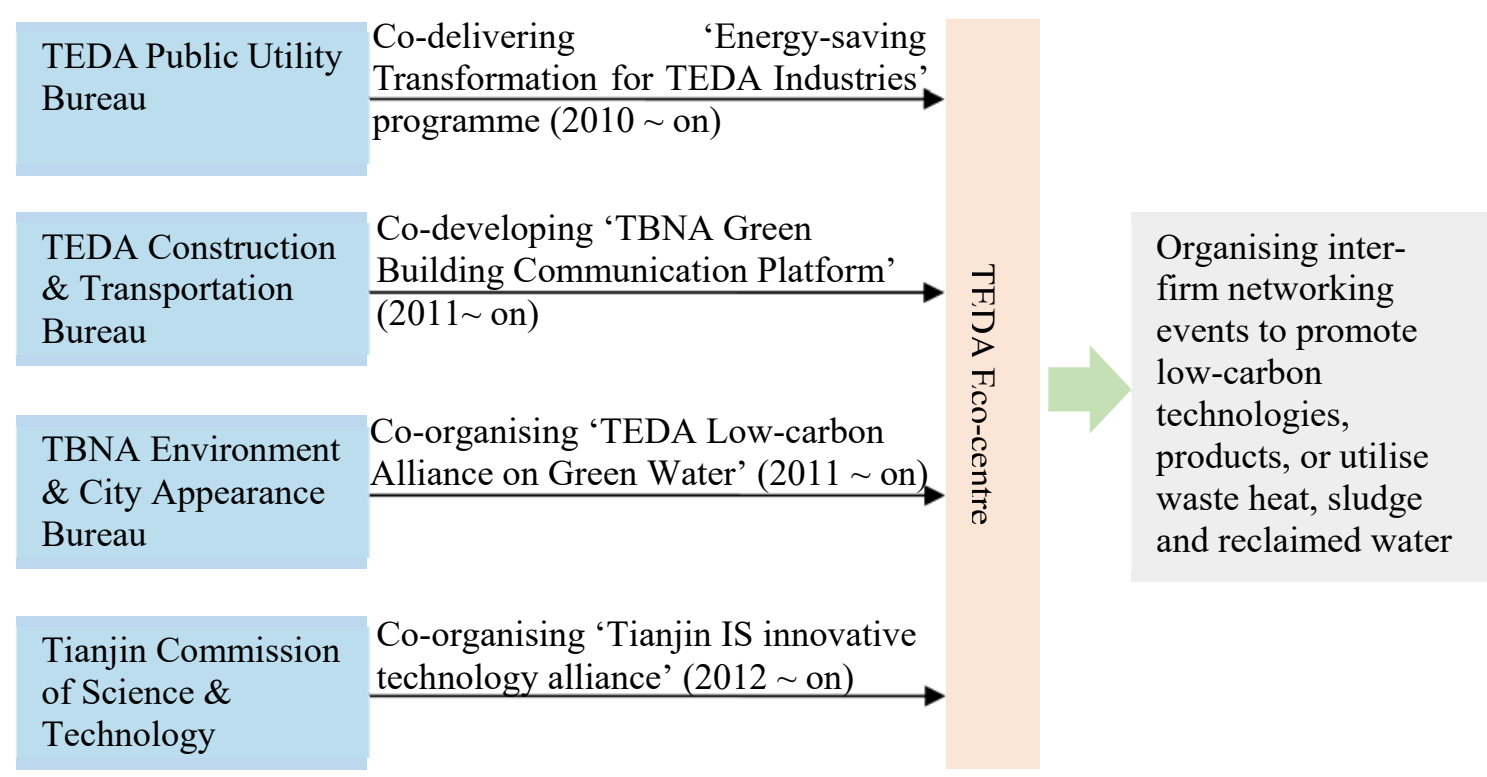

Figure 4. Major coordination activities undertaken with TEDA Eco-centre and government departments which joined the coordination network after 2010 Source: The author generated through drawing upon monthly magazine of Low-carbon TEDA (http://www.ecoteda.org/)

Figure 3 presents original 12 IS coordination network members at March 2010. The size of the coordination network expended with the involvement of TEDA Public Utility Bureau, TEDA Construction and Transportation Bureau, TBNA Environment and City Appearance Bureau, Tianjin Municipal Commission of Science and Technology (as illustrated in Figure 4).

Compared to the original IS coordination structure involving only one coordinator (TEDA EPB), the updated IS coordination network structure shows that all park-level and regional government departments in charge of industrial pollution reduction, energy conservation and low-carbon technologies have participated in the IS coordination network. The eco-centre potentially brought together the power or resources of various government departments to coordinate inter-firm IS activities on topics of utilising waste heat, sludge and reclaimed water, as well as to promote other low-carbon activities such as introducing low-carbon technologies and products.

Regarding the development of personal relationships in the IS coordination network, these were found to be generated through participation in meetings/tours, and actions to reduce the cultural gap. One of the key strengths of the IS coordination network is 
its ability to get a wide range of policy makers from different levels and sectors of government departments, and experts from private and public sectors communicating on how to manage problems promoting IS activities in TEDA and its surrounding area. The first author assisted TEDA representatives' UK policy tours three times. The representatives from government departments listed in Figures 3 and 4 were observed to talk jokes, chat like friends, and help each other such as taking photos on the journey. The policy tours and meetings brought people together. People previously did not work in the same department therefore got more opportunities to know each other and personal relationships among the network coordination members were potentially enhanced.

With the awareness of cultural differences between themselves and the Chinese network actors, ISL recruited a Chinese trainee (the first author who was studying UK waste management strategies) into its international project management department to undertake the following responsibilities:

- Teaching ISL staff about Chinese culture;

- Facilitating Chinese network actors' policy tours to the UK and understanding of UK waste policy context.

In addition, a number of staff with overseas studying background and Englishspeaking skills were recruited into TEDA Eco-centre to communicate with ISL representatives to set up strategies coordinating local IS activities.

\subsubsection{Mobilisation capacity}

Regarding the mobilisation capacity of the case, enthusiasm existed among coordination network members to activate the exchange and development of knowledge and relational resources. For TEDA AC, the project was an opportunity to capture funding for its ambition to develop EIP. The lead funding applicant of the TBNA IS project is TEDAAC (Switch-Asia, 2012). Besides being actively involved in the launch event of TEDA Eco-centre to promote the TBNA IS project to local industries, TEDA $\mathrm{AC}$ also held meetings with top managers of local industries and encouraged them to participate in synergy events organised by TEDA Eco-centre. For other municipal government departments in the IS coordination network, the project also fulfilled the key strategy objectives for regional CE development. Also, for ISL, it was a good 
opportunity to disseminate its information and communications technology-based IS coordination technology to the Chinese market.

With the formation of the IS coordination network, consistent business events promoting resource utilisation and low carbon technologies/products were provided to local industries as shown in Figure 5.

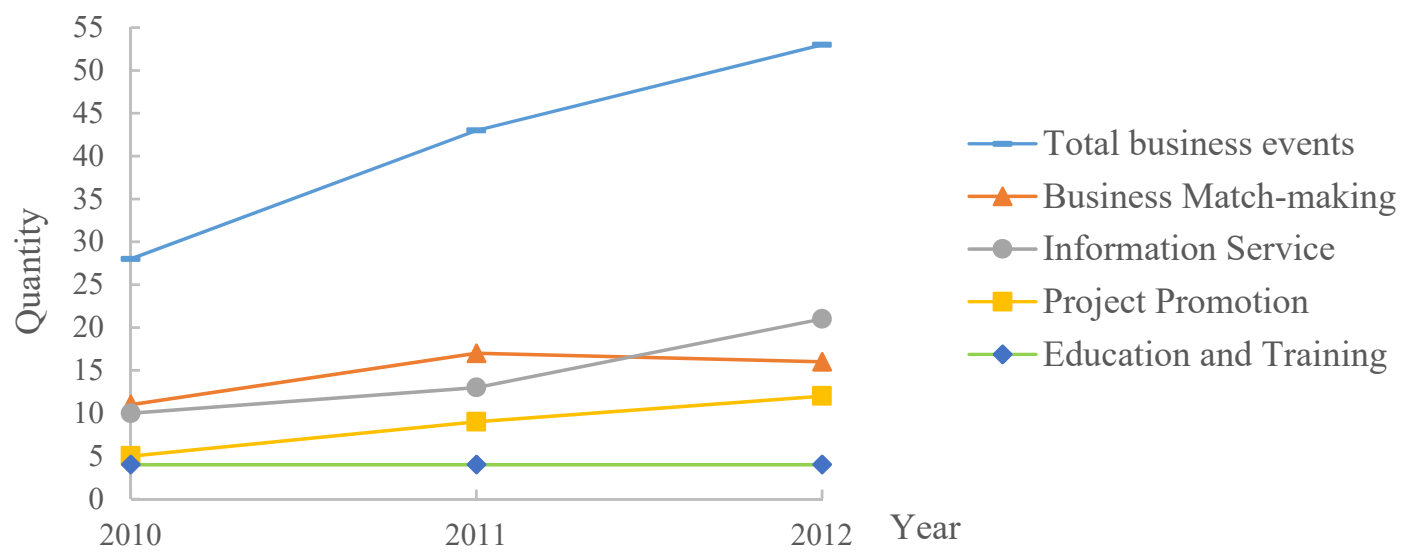

Figure 5 Business Events organised by TEDA Eco-centre and other IS coordination network members between 2010 and 2012

Source: The authored generated drawing upon monthly magazine of Low-carbon TEDA (http://www.ecoteda.org/)

Figure 5 illustrates the frequency of business events organised by TEDA Eco-centre and other IS network coordination members between 2010 and 2012. In this research, 'business match-making' is classified as workshops for increasing interactions between companies with the potential to use other's by-products or low carbon technologies/products, and follow-up service to forward the collaboration; 'Information service' refers to events collecting technologies and experiences (e.g. conducting UK policy tours) to implement IS; 'Project promotion' is defined as events to launch new projects (e.g. Energy-saving Transformation for TEDA Industries' programme) and steering committee meetings to promote the progress of each project; 'Education and Training' refers to low-carbon training events provided to local industries or communities (e.g. Training to establish ISO14001 Environmental Management System). 
A total of 124 business events organised by TEDA Eco-centre and other coordination members between 2010 and 2012 were recorded in the monthly magazine of LowCarbon TEDA retrieved from TEDA Eco-centre website (http://www.ecoteda.org/), . As shown in Figure 5, there was an annual increase of these events during the period. In addition, a recent email interview with a practitioner of TEDA Eco-centre shows the continuity of IS promotion in TEDA.

\begin{abstract}
"After the termination of the [TBNA IS] project, TEDA Eco-centre was still working on coordinating inter-firm IS as a service platform [...] More than 20 events on energy conversation and pollution reduction are organised annually to coordinate technology match-making on utilising by-products and surplus energy"
\end{abstract}

--- by TEDA Eco-centre staff F, email interview, June 2016

In terms of its concrete impact, the IS coordination network potentially enhanced interfirm networking for resource utilisation. Different from traditional conferences where people sit in rows, the match-making workshops offered round table seats and tea break area. Face-to-face discussion on issues in specified fields (e.g. utilization of steam, energy-saving and green building materials) were made among normally 30-40 companies (ISL, 2013).

People were observed to communicate positively during workshops observed by the first author. This observation is supported by feedback from industrial representatives attending match-making workshops, "The idea [of cross-industrial match-making workshops] is novel. Hope more business opportunities can be achieved" (commented by a recycling company representative, view TEDA Eco-centre, 2010a); "I'm satisfied with the workshop. Hope there are more this type of events in future. It provides a convenient platform for enterprises to communicate and learn from each other" (commented by an electronic company representative, referring to TEDA Eco-centre, 2010b).

It is notable that the number of business match-making events dipped in 2012, whilst the number of information service and project promotion events increased. Comparison with the ISL experience in the UK suggests this change in priority may be due to the need for a focus on providing services (e.g. identifying synergy opportunities and training) to business members recruited through earlier business-matching events 
(Interview with ISL staff A). In addition, the Eco-centre, had the capacity to develop alternative approaches to promoting environmental initiatives for local companies (Figure 5).

Outputs of the TBNA IS project between March 2010 and November 2013 are presented in Figure 6. Compared to the estimated result predicted in the original project proposal (i.e., completing 80 synergies and achieving a total of 165,000 tonnes diversion of waste from landfill), the targets were mostly substantially exceeded. To put the achievement in context, in ISL-led IS programme in the UK West Midlands region, which is comparable to the size of TEDA and its surrounding industrial area, achieved 4,250,000 tonnes landfill diversion in eight years (ISL, 2013). Although a full assessment of the project achievement would require more detailed information on the types of residues exchanged, and the proportion of total residue in the region which these comprised, the results achieved are thus broadly comparable with those of the organisation providing external expertise on its home territory.

1,848,316 Euro from EU SwitchAsia Programme \&1,478,652 Euro from TEDA AC

5 6 Staff fulltime working 4 years

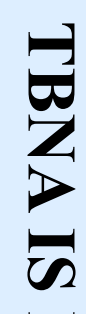

955 business members

574 companies were surveyed

99 facilitated synergies covering utilizing packaging waste, waste plastics, metals, oil \& sludge

1,430,000 tonnes landfill diversion

Figure 6 Input-output streams of TBNA IS project (March 2010-November 2013)

Source: the author generated through drawing upon (ISL, 2013)

In the last year of the project, 2013, there was increased dialogue among TEDA Ecocentre and multiple levels of government departments listed in Figure 3 for strategies to sustain the TBNA IS project after the four-year funding. Further funding for the project was finally gained from the Tianjin Municipal Science and Technology Commission to integrate IS into the planning stage to build an inter-firm IS network (named as Tianjin IS Technology Innovation Alliance) including material and energy 
flows (TEDA Eco-centre, 2012). The alliance targeted improved communication among SMEs, government and research institutions for technology innovation and transformation. Other potential channels such as ministerial level of funding programmes were also identified to increase government recognition of the project providing sustainable support (ISL, 2013).

Regarding the performance of the TBNA IS project, representatives from the UK ISL and TEDA Eco-centre commented that:

"[TEDA] got good results for the level of funding - 1.4 million tonnes landfill diversion over the three years is on the high end. They were the best funded programme outside the UK though."

--- by staff member A from ISL, email interview, January 2016

\begin{abstract}
"With the support of TBNA IS progamme, the eco-centre was established and it has evolved to be a cornerstone to promote low carbon, environmental protection and sustainable development in TEDA"
\end{abstract}

---by TEDA Eco-centre staff F, email interview, June 2016

Thus although the lack of landfill diversion pressure in China hindered early efforts to generate IS in Tianjin (Wang et al 2015), the project has ultimately achieved outcomes to the satisfaction of the IS coordination network members.

\title{
5. Discussion
}

The IS coordination network developed by TEDA AC to deliver the TBNA IS project involved multiple levels of government departments and organisations. The network existed to develop the knowledge resources and relational resources for promoting regional IS development and also had an influence on inter-firm IS activities.

In this qualitative case study, knowledge resources within the IS coordination network can be seen to incorporate policy and networking facilitation knowledge for promoting IS development. This is in contrast to technological knowledge emphasised by Boons and Spekkink's (2012) quantitative study. Also, as Healey et al., (2003) argued, network-level knowledge resources is not a stock of assets that can be disposed of or added to by network members. Rather the knowledge resources draws on the level of 
the implementation of the knowledge contributed by network members collectively towards their goal. For example, this study shows that there were active efforts to implement technological and networking facilitation knowledge from within the network to identify synergy opportunities, organise workshops and follow-up synergy opportunities for industries. Thus the implementation of knowledge gained through the project contributed to the development of knowledge resources contained in a network.

Regarding relational resources, Boons and Spekkink et al. (2012) quantify them through the number of network-related events, such as formal declarations of common goals in a document or master plan for EIP development. In this research, it is argued that relational resources can be developed with new modes of relationship (i.e. new network members were recruited to promote IS) and communication (e.g. periodical network-related events as presented in Figure 5). The network-related activity helped to establish the common goal, i.e., promoting IS.

For the mobilisation capacity of the case study, enthusiasm existed among coordination network members to activate the exchange of knowledge and relational resources. This can be developed from gaining a funding opportunity for local and regional level $\mathrm{CE}$ development and from marketing an IS coordination strategy into a new market (from ISL's perspective) To overcome the lack of policy pressure for landfill diversion (Wang et al., 2015), local government officials worked on promoting the projects to local industries. Similar to Polk (2011), mobilisation capacity of the studied network is explored from perspectives of whether new ways of working for network goal is evident and what concrete impact has the network had on the local area. For the first perspective, it is found that there has been planning to sustain the IS coordination function and the expansion of the coordination network through gaining new funding opportunities. For the second, the concrete impact of the coordination network is valued from the official result of the TBNA IS project and the core network participant's attitude towards its collaborator.

In this IS coordination network, the local government (TEDA AC) has played a crucial role for enhanced institutional capacity for IS development from the following perspectives:

- $\quad$ Recruiting local, national or international coordinating organisations possessing 
necessary policy, technological and network coordination knowledge for IS development;

- Setting up common goal and appointing an non-profit organisation to deliver the network services (such as organising cross-industry workshops and identifying synergy opportunities) to industries;

- Advertising network services to gain attention from local industries and the society;

- Seeking funding opportunities for sustaining the coordination network and fulfilling network goals.

The crucial role that the local government played in this case study provides details about how the industrial area has been transformed into a facilitated EIP as discussed in Yu et al (2014b). This strengthens Patala et al.'s (2014) argument that there is a need to build broad coalitions to address environmental issues such as reducing the environmental load from production and consumption. This research therefore potentially provides lessons to other Chinese industrial areas with the ambition for the CE development involving putting IS into practice.

\section{Conclusions}

This research adopted a qualitative case study approach to explore the transformation of institutional capacity with the development of an IS coordination network in a Chinese industrial area. We have applied ideas relating to institutional capacity building for IS to a new and important context, given the degree to which IS is institutionalised within the Chinese policy framework, and the substantial contribution of Chinese case studies to the academic literature on IS.

Findings suggest that the IS coordination network, with the support of the local government, has been successful. The network exceeded the targets for waste diversion from landfill and the number of IS relationships established required by the EU funding for the collaboration of an international partner. In addition to IS specific activity, a wide range of activities have been organised to promote low carbon technology uptake and environmental protection more generally. This activity appears to reflect the strength of the coordination network. Notwithstanding the top-down nature of Chinese EIP policy, implementing bodies have been able to forge not only local networks to put 
together the knowledge and skills needed, but also to draw on national and international expertise. The use of international expertise to implement IS has been applied elsewhere, as Olayide (2015) reports in Africa. Although indicative of at least a perceived shortage of knowledge locally, working with an international body can itself be an indication of mobilisation capacity, i.e., the ability to identify and engage suitable external expertise. It is a strategy for achieving the balance of necessary and sufficient conditions for IS at a locality. As discussed above, during the lifetime of the project the various coordination network members developed the relational resources needed to work with each other and were able to implement IS on a scale comparable to that achieved by ISL on its home territory in the UK.

Thus drawing on international expertise can be a useful strategy for IS. The initial experiences of this project discussed elsewhere (Wang et al., 2015), illustrate the challenges that can arise from international policy transfer, and need for adjustment to local conditions. The overcoming of the initial challenges suggests that institutional capacity was built locally, not simply imported. A further test to the embeddedness of IS is what happened after the end of the formal collaboration. The ability to coordinate the network and the implementation of activity complementary to IS indicates TEDA AC's capacity to help develop environmental business activity more generally than IS. In this instance the institutional capacity developed is strong for the organisation of networking events, which contributes to the perpetuation of the coordination network as well as to continuing efforts to establish IS. However, the thrust of Chinese resource efficiency regulations is towards low carbon and technological innovation rather than IS specifically (Wang et al. 2015), and TEDA Eco-centre has continued to support these areas, drawing on the institutional capacity built alongside its experience with IS.

Implementing IS requires the mobilisation of knowledge and relational skills beyond the most relevant ones to trying to build a network of companies with IS-relationships. Furthermore, this study shows also the significance of the relationships between the coordination network members. Further research is required to identify different forms of IS coordination networks and assess the level of their institutional capacity to find the most effective forms of coordination strategy for IS development. Successful implementation of IS in a given setting will involve identifying which organisations are 
relevant and/or critical to include and how they relate to the policy framework. In addition, research should consider how organisations within an IS coordination network relate to each other in different geographic and, especially, different political-cultural settings.

\section{Acknowledgements}

Thanks to the anonymous reviewers and Professor Zengwei Yuan's precious opinions towards this article. We greatly appreciated the hospitality and assistance received from TEDA EPB, TEDA Eco-centre and International Synergies Limited staff. This work was supported by research funding from Wuhan University of Science and Technology (project code: 2015XZ009), the China Scholarship Council and the University of Hull.

\section{References}

Baxter, J., 2010. Case studies in qualitative research, in: Hay, I. (Ed.), Qualitative Research Methods in Human Geography. Oxford University Press, Oxford, pp. 81-97.

Boons, F., Howard-Grenville, J.A. (Eds.), 2009. The social embeddedness of industrial ecology. Edward Elgar Publishing Limited, Cheltenham, UK.

Boons, F., Spekkink, W., 2012. Levels of Institutional Capacity and Actor Expectations about Industrial Symbiosis. J. Ind. Ecol. 16, 61-69. doi:10.1111/j.1530-9290.2011.00432.x

Boons, F., Spekkink, W., Mouzakitis, Y., 2011. The dynamics of industrial symbiosis: a proposal for a conceptual framework based upon a comprehensive literature review. J. Clean. Prod. 19, 905-911. doi:10.1016/j.jclepro.2011.01.003

Breukers, S., Wolsink, M., 2007. Wind energy policies in the Netherlands: Institutional capacity-building for ecological modernisation. Env. Polit. 16, 92112. doi:10.1080/09644010601073838

Chertow, M., Ehrenfeld, J., 2012. Organizing Self-Organizing Systems. J. Ind. Ecol. 16, 13-27. doi:10.1111/j.1530-9290.2011.00450.x

Chertow, M.R., 2000. Industrial Symbiosis: Literature and Taxonomy. Anna. Rev. Energy Environ. 25, 313-317.

Creswell, J.W., 2012. Qualitative Inquiry and Research Design: Choosing Among Five Approaches., Third. ed. SAGE. 
Deutz, P., 2014. Food for thought: seeking the essence of Industrial Symbiosis, in: Salomone, R., Saija, G., Ioppolo, G. (Eds.), Pathways to Environmental Sustainability: Methodologies and Experiences. pp. 3-11.

Deutz, P., Gibbs, D., 2008. Industrial ecology and regional development: ecoindustrial development as cluster policy. Reg. Stud. 42, 1313-1328. doi:10.1080/00343400802195121

DeWalt, K.M., DeWalt, B.R., 2011. Participant observation : a guide for fieldworkers, 2nd ed. AltaMira Press, Plymouth.

Dietrich, P., 2007. Coordination Strategies in Organisational Development Programs. Helsinki University of Technology.

Doménech, T., Davies, M., 2011. The role of embeddedness in industrial symbiosis networks: Phases in the evolution of industrial symbiosis networks. Bus. Strateg. Environ. 281-296.

EMCP, 2013. Introduction [WWW Document]. URL http://www.acca21.org.cn/EU/epart.html

Geng, Y., Zhao, H., 2009. Industrial Park Management in the Chinese Environment. J. Clean. Prod. 17, 1289-1294.

Geng, Y., Zhu, Q., Haight, M., 2007. Planning for integrated solid waste management at the industrial park level: a case of Tianjin, China. Waste Manag. 27, 141-50. doi:10.1016/j.wasman.2006.07.013

Granovetter, M., 1985. Economic action and social structure: the problem of embeddedness. Am. J. Sociol. 91, 481-510.

Healey, P., 1998. Building institutional capacity through collaborative approaches to urban planning. Environment and Planning A. Environ. Plan. A 30, 1531-1546.

Healey, P., 2015. Civil society enterprise and local development. Plan. Theory Pract. 16, 11-27. doi:10.1080/14649357.2014.995212

Healey, P., De Magalhaes, C., Madanipour, A., Pendlebury, J., 2003. Place, identity and local politics: analysing initiatives in deliberative governance, in: Hajer, M.A., Wagenaar, H. (Eds.), Deliberative Policy Analysis: Understanding Governance in the the Network Society. Cambridge University Press, Cambridge, pp. 60-87.

Hewes, A., Lyons, D., 2008. The Humanistic Side of Eco-industrial Parks: Champions and the Role of Trust. Reg. Stud. 42, 1329-1342.

ISL, 2013. TEDA Final Report. 
Jacobsen, N.B., 2006. Industrial Symbiosis in Kalundborg, Denmark: a quanlittive assessment of economic and environmental aspects. J. Ind. Ecol. 10, 239-255.

Jensen, P.D., Basson, L., Hellawell, E.E., Bailey, M.R., Leach, M., 2011. Quantifying "geographic proximity": Experiences from the United Kingdom's National Industrial Symbiosis Programme. Resour. Conserv. Recycl. 55, 703-712. doi:10.1016/j.resconrec.2011.02.003

Jiao, W., Boons, F., 2014. Toward a research agenda for policy intervention and facilitation to enhance industrial symbiosis based on a comprehensive literature review. J. Clean. Prod. 67, 14-25. doi:10.1016/j.jclepro.2013.12.050

Liu, L., Zhang, B., Bi, J., 2015. Institutional context of Eco-Industrial Parks development in China: Environmental governance in industrial parks and zones, in: Deutz, P., Boons, F. (Eds.), International Perspectives on Industrial Ecology.

Marques, L., Ribeiro, J. a., Scapens, R.W., 2011. The use of management control mechanisms by public organizations with a network coordination role: A case study in the port industry. Manag. Account. Res. 22, 269-291. doi:10.1016/j.mar.2011.09.001

Mathews, J. a., Tan, H., 2011. Progress Toward a Circular Economy in China. J. Ind. Ecol. 15, 435-457. doi:10.1111/j.1530-9290.2011.00332.x

McGuire, M., Agranoff, R., 2011. The Limitations of Public Management Networks Public Administration. Public Adm. 89, 265-284.

Mirata, M., 2004. Experiences from early stages of a national industrial symbiosis programme in the UK: determinants and coordination challenges. J. Clean. Prod. 12, 967-983. doi:10.1016/j.jclepro.2004.02.031

Mirata, M., Emtairah, T., 2005. Industrial symbiosis networks and the contribution to environmental innovation. J. Clean. Prod. 13, 993-1002. doi:10.1016/j.jclepro.2004.12.010

Olayide, O., 2015. Industrial Ecology, Industrial Symbiosis and Ecological Industrial Parks in Africa: Issues for Sustainable Development, in: Duetz, P., Lyons, D., Bi, J. (Eds.), International Perspectives on Industrial Ecology. Edward Elgar Publishing Limited, Cheltenham, UK, pp. 30-45.

Paquin, R.L., Howard-Grenville, J., 2012. The Evolution of Facilitated Industrial Symbiosis. J. Ind. Ecol. 16, 83-93. doi:10.1111/j.1530-9290.2011.00437.x Park, H.-S., Rene, E.R., Choi, S.-M., Chiu, A.S.F., 2008. Strategies for sustainable development of industrial park in Ulsan, South Korea--from spontaneous 
evolution to systematic expansion of industrial symbiosis. J. Environ. Manage. 87, 1-13. doi:10.1016/j.jenvman.2006.12.045

Patala, S., Hämäläinen, S., Jalkala, A., Pesonen, H.-L., 2014. Towards a broader perspective on the forms of eco-industrial networks. J. Clean. Prod. 82, 166-178. doi:10.1016/j.jclepro.2014.06.059

Polk, M., 2011. Institutional Capacity-building in Urban Planning and Policy-making for Sustainable Development: Success or Failure? Plan. Pract. Res. 26, 185-206. doi:10.1080/02697459.2011.560461

Provan, K.G., Kenis, P., 2008. Modes of Network Governance: Structure, Management, and Effectiveness. J. Public Adm. Res. Theory 18, 229-252. doi:10.1093/jopart/mum015

Qi, Y., Li, H., Wang, J., 2009. Promoting industrial symbiosis network through public-private partnership: a case study of TEDA, in: ICBBE. IEEE, Beijing, pp 1-4. doi:10.1109/ICBBE.2009.5163251

Rehn, S., 2013. Influencing industrial symbiosis development, a case study of Händelö and Northern Harbour Industrial Areas. Linkopings University.

Schiller, F., Penn, A.S., Basson, L., 2014. Analyzing networks in industrial ecology a review of Social-Material Network Analyses. J. Clean. Prod. 76, 1-11. doi:10.1016/j.jclepro.2014.03.029

Shi, H., Chertow, M., Song, Y., 2010. Developing country experience with ecoindustrial parks: a case study of the Tianjin Economic-Technological Development Area in China. J. Clean. Prod. 18, 191-199. doi:10.1016/j.jclepro.2009.10.002

Shi, H., Tian, J., Chen, L., 2012. China’s Quest for Eco-industrial Parks, Part I. J. Ind. Ecol. 16, 8-10. doi:10.1111/j.1530-9290.2012.00454.x

Shi, L., Yu, B., 2014. Eco-industrial parks from strategic niches to development mainstream: The cases of China. Sustain. 6, 6325-6331. doi:10.3390/su6096325

Sokka, L., Pakarinen, S., Melanen, M., 2011. Industrial symbiosis contributing to more sustainable energy use - an example from the forest industry in Kymenlaakso, Finland. J. Clean. Prod. 19, 285-293. doi:10.1016/j.jclepro.2009.08.014

Spekkink, W., 2013. Institutional capacity building for industrial symbiosis in the Canal Zone of Zeeland in the Netherlands: a process analysis. J. Clean. Prod. 52, 342-355. doi:10.1016/j.jclepro.2013.02.025 
State Council, 2005. Several Opinions of the State Council on Speeding up the Development of the Circular Economy Development (Chinese).

Switch-Asia, 2012. Implementing Industrial Symbiosis and Environmental Management Systems in Tianjin Binhai New Area [WWW Document]. URL http://www.switch-asia.eu/switch-projects/project-impact/projects-on-improvingproduction/industrial-symbiosis.html

TEDA, 2005. "EU-China" Collaborative Programme [WWW Document]. URL http://teda.gov.cn/html/hjbhj/ZOHJ17486/List/tdxmjs.html

TEDA, 2011a. TEDA Overview [WWW Document]. URL http://www.chnsourcing.com/outsourcing-news/parks/tianjin_teda/ TEDA, 2011b. Basic Facts [WWW Document]. URL http://en.investteda.org/aboutteda/sections/tianjinteda/default.htm

TEDA AC, 2006. Implementation strategy for pilot circular economy development (天津开发区循环经济试点实施方案).

TEDA AC, 2009. Switch-Asia Promoting Sustainable Consumption and Production Grant Application Form: Implementing Industrial Symbiosis and Environmental Management Systems in Tianjin Binhai New Area.

TEDA Eco-centre, 2010a. Match-making workshops of EU Industrial Symbiosis Programme. Low carbon TEDA 27.

TEDA Eco-centre, 2010b. Mach-making workshop. Low carbon TEDA 14.

TEDA Eco-centre, 2011. The Introduction of the TEDA Eco-centre.

TEDA Eco-centre, 2012. The strategy to set up the Tianjin IS Innovative Technology Alliance.

Van Beers, D., Bossilkov, A., Corder, G., Berkel, R., 2008. Industrial Symbiosis in the Australian Minerals Industry: The Cases of Kwinana and Gladstone. J. Ind. Ecol. 11, 55-72. doi:10.1162/jiec.2007.1161

Van Hoof, B., Thiell, M., 2015. Anchor company contribution to cleaner production dissemination: Experience from a Mexican sustainable supply programme. J. Clean. Prod. 86, 245-255. doi:10.1016/j.jclepro.2014.08.021

Wang, Q., 2013. Knowledge Transfer to Facilitate Industrial Symbiosis: A Case Study of UK-China Collaborators. University of Hull.

Wang, Q., Deutz, P., Gibbs, D., 2012. UK's waste policy frame work for ISD: lessons for China?, in: 18th Annual International Sustainable Development Research 


\section{Conference.}

Wang, Q., Deutz, P., Gibbs, D., 2015. UK-China collaboration for industrial symbiosis: a multi-level approach to policy transfer analysis, in: Duetz, P., Lyons, D., Bi, J. (Eds.), International Perspectives on Industrial Ecology. Edward Elgar Publishing Limited, Cheltenham, UK, pp. 89-107.

Wang, Y., 2010. TEDA Strives for Energy Efficiency with International Help. Chinadaily 20.

Yin, R.K., 2008. Case Study Research Design and Methods. SAGE, Thousand Oaks, California.

Yin, R.K., 2012. Applications of Case Study Research. SAGE, Thousand Oaks, California.

Yu, C., Davis, C., Dijkema, G.P.J., 2014a. Understanding the Evolution of Industrial Symbiosis Research. J. Ind. Ecol. 18, 280-293. doi:10.1111/jiec.12073

Yu, C., de Jong, M., Dijkema, G.P.J., 2014b. Process analysis of eco-industrial park development-the case of Tianjin, China. J. Clean. Prod. 464-477. doi:10.1016/j.jclepro.2013.09.002

Yu, C., Dijkema, G.P.J., de Jong, M., 2014c. What makes eco-transformation of industrial parks take off in China? J. Ind. Ecol. 19, 441-456. doi:10.1111/jiec.12185

Yu, F., Han, F., Cui, Z., 2015. Evolution of industrial symbiosis in an eco-industrial park in China. J. Clean. Prod. 87, 339-347. doi:10.1016/j.jclepro.2014.10.058

Zhang, L., Yuan, Z., Bi, J., Zhang, B., Liu, B., 2010. Eco-industrial parks: national pilot practices in China. J. Clean. Prod. 18, 504-509. doi:10.1016/j.jclepro.2009.11.018 